\title{
ТЕХНИКО-ТЕХНОЛОГИЧЕСКИЕ
}

ИННОВАЦИИ

DOI: http://dx.doi.org/10.15688/jvolsu10.2015.2.3

УДК 621.1

ББК 31.3

\section{INVESTIGATION OF REACTION OF ETHYLENE TELOMERIZATION}

\section{Chkhubianishvili Nodar}

Doctor of Technical Sciences, Professor,

Faculty of Chemical Technology and Metallurgy,

Georgian Technical University

rusikoch@yahoo.com

Kostava St., 77, 0175 Tbilisi, Georgia

\section{Kristesashvili Lali}

Doctor of Technical Sciences, Professor,

Faculty of Chemical Technology and Metallurgy,

Georgian Technical University

rusikoch@yahoo.com

Kostava St., 77, 0175 Tbilisi, Georgia

\begin{abstract}
The interest towards radical telomerization is conditioned by the fact that it enables to obtain comparably low-molecular long-chain organic substances with various functional groups that are hard to obtain with ordinary methods and that can be widely applied in practice. The reaction of telomerization of ethylene and trichloracetic acid ethyl ester [3] is especially interesting. The reaction proceeds in the following way:
\end{abstract}

$$
\mathrm{nCH}_{2}=\mathrm{CH}_{2}+\mathrm{CCl}_{3} \mathrm{COOEt} \rightarrow \mathrm{Cl}\left(\mathrm{CH}_{2} \mathrm{CH}_{2}\right) \mathrm{nCCl}_{2} \mathrm{COOEt}
$$

Telomers, received from ethylene and trichloracetic acid esters, are utilized to obtain the psychotropic drug Gamalon, $\varepsilon$-Capron ( $\varepsilon$-hexanoic acid) and biological active substances Ly-sin and methion.

Key words: reaction, telomerization, ethylene, trichloracetic acid, ethyl ester, mechanism, reactivity. 


\section{Results and Discussions}

\section{Telomerization of Ethylene and Trichlororoacetic acid}

In order to study this reaction, a series of autoclave experiments were conducted: we had an experiment with the equipment which is presented in Fig. 1. It was a $200 \mathrm{~cm}^{3}$-volume stainless steel autoclave (1) which was equipped with electromagnetic stirrer (2) and a pocket of thermocouple. We added solution of initiator to telogen. During each experiment $103.5 \mathrm{~g}(75 \mathrm{ml})$ of trichloracetic acid ethyl ester was loaded into the autoclave under the conditions of high pressure and closed valves $(4,5,11)$. The autoclave was cooled at up to $-20-25{ }^{\circ} \mathrm{C}$ and the vacuum in the system was created through the valve (6) connected to a vacuum line. The residual pressure was $5-10 \mathrm{mmHg}$. Then we closed the valve $(6)$, opened valves $(4,11)$ and delivered ethylene to evacuate air. Ethylene was delivered from the balloon (7). The autoclave was warmed up to room temperature, electromagnetic stirrer was turned on and telogen was saturated with ethylene to defined pressure of manometer (9). Once pressure decay was stopped, the autoclave was placed into the thermostat $(8)$ and heated to the reaction temperature. Liquid silicone was used as a heat transmitter. The stirring in the autoclave was done with nitrogen sparging. The temperature was regulated via contact thermometer connected to the network through electromagnetic switch. The control over telomerization was implemented according to the pressure decay on the manometer (9). The reaction was conducted until the drop of ethylene pressure was finished. Calculation of the amount of ethylene loaded into the autoclave was determined by ethylene amounts reacted (based on the data of telomers composition) and returned after the reaction or by solubility of ethylene.

For security reasons, the equipment was outfitted with blasting plate (10) designed for 200 atmospheric pressure and emergency valve (11).

After finishing the reaction, autoclave was cooled down to room temperature. Throttling of non-reacted ethylene was done in fixer (12). It was cooled down to $-15-20{ }^{\circ} \mathrm{C}$ in Dewar vessel and was collected in gasometer (14). The fixer was installed to hold the reaction mass taken away during throttling. After throttling of air, reaction products were removed, nonreacted initial ester was removed by distillation and the mix of telomeres was distilled on the rectifying column of 7-10 theoretical plate effectiveness.

Samples were analyzed on air-liquid chromatograph, on heat-conducting detector.

It was established that the product chromatogram had 4 peaks (see Fig. 2):

1 - corresponded to telomer $n_{1}, 1,1,3$ thrichlorerbor acid ethyl ester;

2 - corresponded to telomer $n_{2}, 1,1,5$ thrichlorcapron acid ethyl ester;

3 - corresponded to telomer $n_{3}, 1,1,7-$ thrichlorcapril acid ethyl ester;

4 - corresponded to telomer $n_{4}$, high molecule esther.

Besides, the identity of telomers was established by boiling temperature, density, refraction, infrared spectroscopy and element analysis.

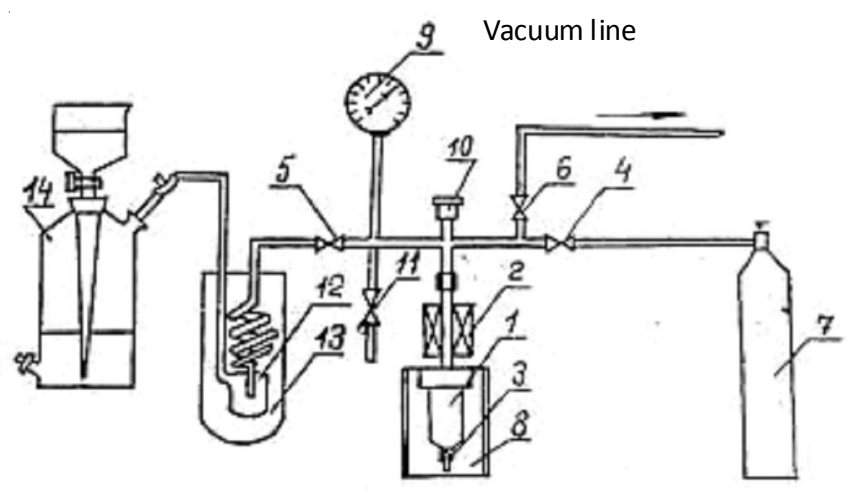

Fig. 1. The scheme of the equipment to carry out the reaction of telomerization in the intermittently operational autoclave 


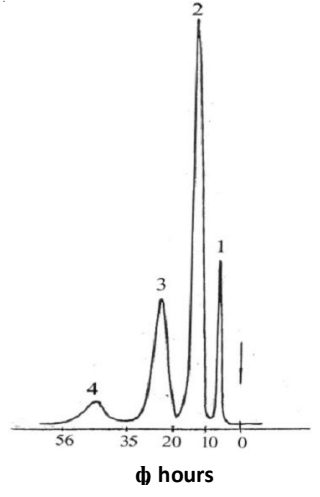

Fig. 2. Chromatogram of telomer mix:

$$
1-n_{1} ; 2-n_{2} ; 3-n_{3} ; 4-n_{4}
$$

Thermodynamics of the Reaction of Telomerization of Ethylene and Trichloracetic Acid Ethyl Ester

The telomerization reaction is an exothermic process. The approximate estimation of thermal effect of the reaction is possible through the energy of chemical bonds. The total thermal effect of telomerization reactions is mostly determined by the energies of breaking double $\mathrm{C}=\mathrm{C}$ bonds and generation of single $\mathrm{C}=\mathrm{C}$ bonds.

There is no data available in the literature about thermodynamic characteristics of the reaction of telomerization of ethylene and trichloracetic acid ethyl ester. That is why we estimated standard thermal effect of the reaction, coefficients of heat capacity equation $c^{p}=\varphi(\mathrm{T})$, and entropy for initial and final products of the reaction based on molecular structure with group revision method [2]. Results are reported in Table 1; Fig. 3 shows dependence of $\Delta F$ and $\operatorname{Lg} K_{p}$ values on temperature. Approximate values of temperature allowing the reaction to be conducted thermodynamically are determined graphically.

As long as the reaction of telomerization takes place in liquid but not in air phase, calculations of thermal effects of reaction should take into account heat of phase transition - heat of condensation of trichloracetic acid ethyl ester and telomers, and heat of dilution of ethylene into the telogen. The heat of dilution of telomers in telogens can be ignored.
Combination of reaction equation and phase transformation equation leads to the following:

1. For 1,1,3-trichlor butyric acid ethyl ester (telomer $n_{1}$ ):

$$
\Delta H_{c_{6}}^{\prime}=\Delta H_{c_{6}}-\Delta H_{\text {telog.dilut }}+\Delta H_{\text {telog.evapor }}-\Delta H_{c_{6} \text { evapor }}
$$

2. For 1,1,5 - trichlor hexanoic acid ethyl ester:

$$
\Delta H_{c_{8}}^{\prime}=\Delta H_{c_{8}}-2 \Delta H_{\text {ester.dilut }}+\Delta H_{\text {telog.evapor }}-\Delta H_{c_{8} \text { evapor }}
$$

3. For 1,1,7 - trichlor hexyl acetic acid ethyl ester:

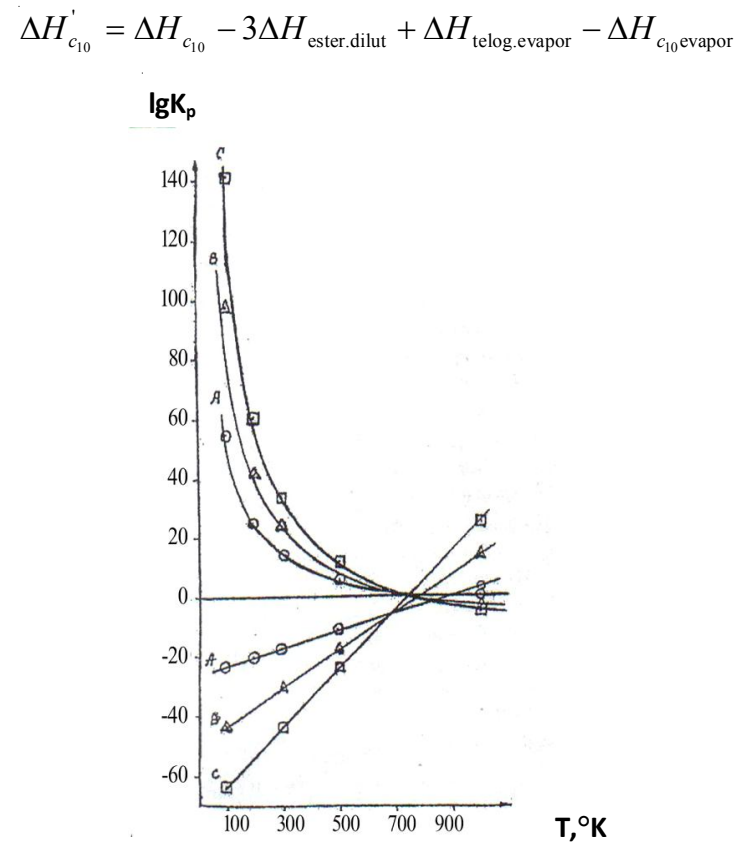

Fig. 3. The dependence of equilibrium constant logarithm and $\Delta F$ isobaric potential on temperature for $A, B, C$ telomerization reactions

The heat of evaporation of trichloracetic acid and telomers is calculated with respective empirical formula through extrapolation of boiling temperature data:

$$
\Delta H_{\text {evapor }} \mathrm{H} \approx\left(8.75+4.575 \lg T_{\text {boil }}\right) * T_{\text {boil }}
$$

In Fig. 3, the heat of ethylene dilution in trichloracetic acid ethyl ester is $\sim 3.5 \mathrm{kcal} /$ $\mathrm{mol}=14.5 \mathrm{kj} / \mathrm{mol}$.

Table 1

Standard thermal effects and entropy increment of reactions

\begin{tabular}{|l|c|c|c|}
\hline$\#$ & \multicolumn{1}{|c|}{ Reaction } & $\begin{array}{c}\Delta \mathrm{H}_{298} \\
\mathrm{kcal} / \mathrm{mol}\end{array}$ & $\begin{array}{c}\Delta \mathrm{S}_{298} \\
\mathrm{kcal} / \mathrm{mol}\end{array}$ \\
\hline A & $\mathrm{CCl}_{3} \mathrm{COOC}_{2} \mathrm{H}_{5}+\mathrm{C}_{2} \mathrm{H}_{4} \rightarrow \mathrm{Cl}\left(\mathrm{CH}_{2} \mathrm{CH}_{2}\right) \mathrm{CCl}_{2} \mathrm{COOC}_{2} \mathrm{H}_{5}$ & -27.7 & -31.1 \\
\hline B & $\mathrm{CCl}_{3} \mathrm{COOC}_{2} \mathrm{H}_{5}+2 \mathrm{C}_{2} \mathrm{H}_{4} \rightarrow \mathrm{Cl}\left(\mathrm{CH}_{2} \mathrm{CH}_{2}\right)_{2} \mathrm{CCl}_{2} \mathrm{COOC}_{2} \mathrm{H}_{5}$ & -50.8 & -65.5 \\
\hline $\mathrm{C}$ & $\mathrm{CCl}_{3} \mathrm{COOC}_{2} \mathrm{H}_{5}+3 \mathrm{C}_{2} \mathrm{H}_{4} \rightarrow \mathrm{Cl}\left(\mathrm{CH}_{2} \mathrm{CH}_{2}\right)_{3} \mathrm{CCl}_{2} \mathrm{COOC}_{2} \mathrm{H}_{5}$ & -73.9 & -100.1 \\
\hline
\end{tabular}




$$
\begin{aligned}
\Delta H_{c_{6}}^{\prime}=27.7+3.5+9.5-10.5= & 30.2 \mathrm{kcal} / \mathrm{mol}= \\
& =126.5 \mathrm{kj} / \mathrm{mol} \\
\Delta H_{c_{8}}^{\prime}=50.8+23.5+9.5-11.4 & =55.9 \mathrm{kcal} / \mathrm{mol}= \\
& =234.2 \mathrm{kj} / \mathrm{mol} \\
\Delta H_{c_{10}}^{\prime}=73.9+3.35+9.5-11.9 & =82.0 \mathrm{kcal} / \mathrm{mol}= \\
& =343.6 \mathrm{kj} / \mathrm{mol}
\end{aligned}
$$

The data shows that thermal effect of these reactions in liquid phase is slightly different from that in air phase. Therefore, thermal effect of telomerization of ethylene and trichloracetic acid ethyl ester is about $28.5 \mathrm{kcal} / \mathrm{mol}(119.3 \mathrm{kj} / \mathrm{mol})$ on 1 mol ethylene which is close to polymerization heat of ethylene $(30 \mathrm{kcal} / \mathrm{mol})$.

Solubility of Ethylene in Trichloracetic Acid Ethyl Ester

To study kinetics of telomerization reactions the condition of air and liquid phases is of big importance as it determines liquid and air phase composition, dependence of reaction speed on components' concentration.

The solubility of ethylene was studied on special equipment (Fig. 4).

Vacuum

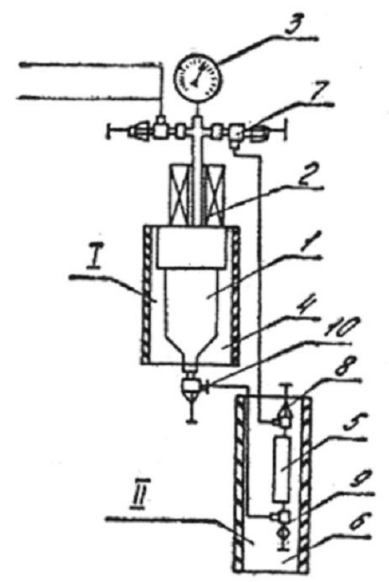

Fig. 4. The scheme of the equipment for studying ethylene solubility

The creation of vacuum in the equipment was done under the conditions of opened valves of both systems. We closed valves (10) and (7) and loaded trichloracetic acid ethyl ester into the autoclave. The thermostat of the autoclave was cooled down to $-15 \div 20^{\circ} \mathrm{C}$. Then we opened valve (7) and created vacuum in the system. Subsequently we closed the vacuum line and supplied the systems with ethylene. The required temperature was reached in both thermostats and the stirrer. We turned the equipment off from ethylene delivery line and observed the termination of the saturation of trichloracetic acid ethyl ester with ethylene by ending the pressure decay. After that, we closed the stirrer, opened the valve (10) and the systems remained under similar temperature during one hour. Then the valves $(7-10)$ were closed and the second system was separated from the first. The solubility of ethylene was studied under different pressure and temperature.

Air solubility depends on the nature of air and solvent, temperature and pressure. The association between air solubility and partial pressure is expressed by Henry's Law:

$$
N_{2}^{\prime}=k P_{2}
$$

Where: $N_{2}^{\prime}$ - is a molar fraction of liquid soluble air; $P_{2}$ - partial pressure of air; $k$ - Henry's law constant (atmospheric/molar fraction).

Ethylene solubility under different pressure and temperature is shown in Fig. 5. The figure shows that ethylene solubility is directly proportional to ethylene pressure and responds to Henry's law. Out of experimental data, we calculated Henry's law constant at $25,90,100,120^{\circ} \mathrm{C}$ and it was respectively $0.428,1.195,1.395$ and 1.725 .

P, atm

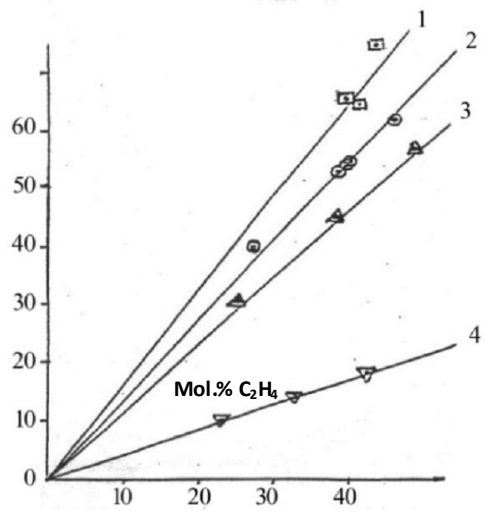

Fig. 5. Ethylene solubility in trichloracetic ethyl ester at various pressure and temperature:

$1-120^{\circ} \mathrm{C} ; 2-100{ }^{\circ} \mathrm{C} ; 3-90{ }^{\circ} \mathrm{C} ; 4-25^{\circ} \mathrm{C}$

Based on these data we found the heat of ethylene dilution in trichloracetic acid ethyl ester. For this reason, we designed the curve representing association between logarithm of Henry's law constant and inverse of absolute temperature. This association is shown in Fig. 6, which is drawn as a straight line and tangent of its angle is a thermal heat of ethylene. 
$\lg K$

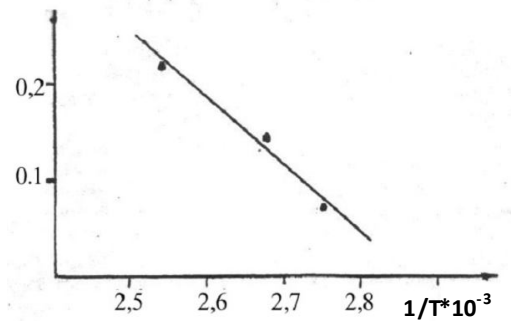

Fig. 6. Dependence of logarithm of Henry's law constant on inverse of absolute temperature in the

system - ethylene trichloracetic acid ester

The diagram and Arrhenius equation help determine ethylene dilution heat, which is approximately $3.5 \mathrm{kcal} / \mathrm{mol}$.

Fig. 7 shows the dependence of molar volumes of studied solutions on pressure and temperature. It is clear that the change of molar volumes of solutions is directly proportional to pressure in the area of temperature and pressure of the research interest.

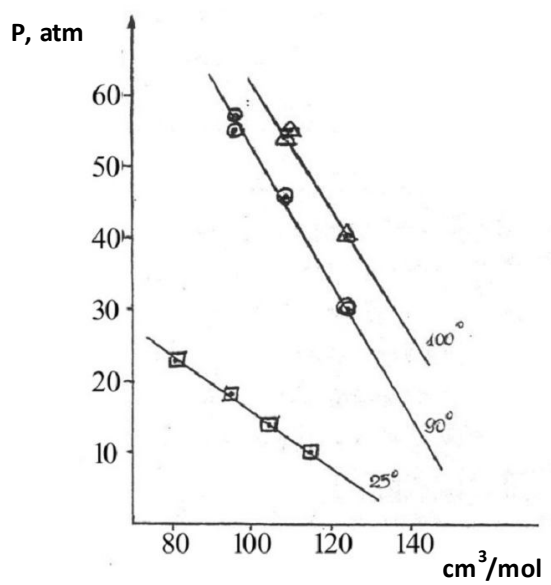

Fig. 7. Dependence of molar volumes of ethylene solution on pressure at 25,90 , and $100^{\circ} \mathrm{C}$ temperature

The goal of conducted series of autoclave experiments of telomerization of Ethylene and trichloracetic ethyl ester was to study the following issues:
1. Effect of temperature on the yield and composition of telomers.

2. Effect of concentration of initiator on the yield and composition of telomers.

3. Effect of mixture of initial reagents on the composition of telomers.

\section{Effect of Temperature}

One of the important factors for telomerization reactions is reaction temperature. It determines the velocity of dissociation of the initiator and reaction potential of reacting components and affects the chain transmission constants. The effect of temperature on ethylene conversion was studied under the conditions of loading equal quantities of reagents. Fig. 8 depicts the dependence of ethylene conversion on temperature.

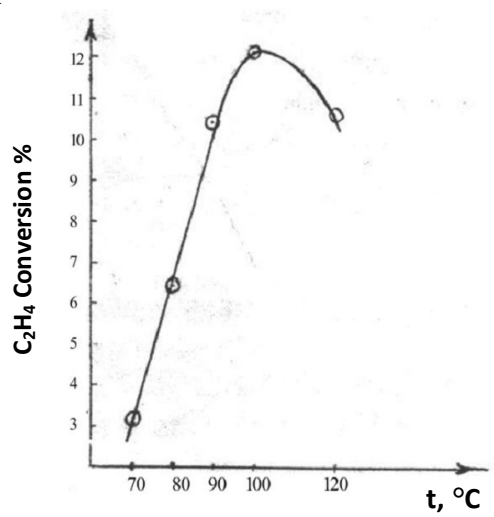

Fig. 8. Dependence of ethylene conversion on temperature

The highest conversion of ethylene is achieved at $100{ }^{\circ} \mathrm{C}(12.3 \mathrm{~mol} \%)$. Conversion is reduced through decreased temperature, which can be attributable to incomplete dissociation of initiator. Temperature increase above $100{ }^{\circ} \mathrm{C}$ considerably raises the recombination velocity of initiator's free radicals.

Fig. 9 describes the dependence of pressure decay on time at various temperatures. As far as velocity of telomerization reaction is limited

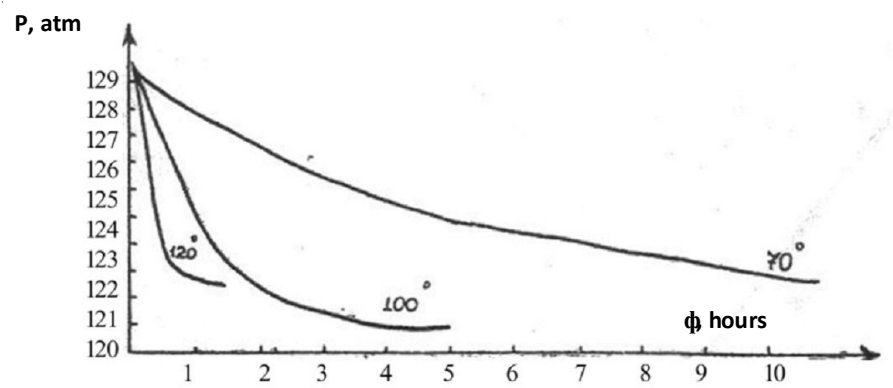

Fig. 9. Pressure drop dependence on time at various temperatures 
by the velocity of dissociation of initiator, the data of pressure decay can be used to determine the velocity of telomerization. As shown in Fig. 9, the duration of reaction at $70{ }^{\circ} \mathrm{C}$ is 10.5 hours, while the reactions at 100 and $120^{\circ} \mathrm{C}$ end in $\sim 4.5$ and 1.5 hours, respectively

\section{Effect of Initiator}

According to kinetic equation of telomerization, the velocity of telomer yield is proportional to initiator concentration in power $1 / 2$ (for squared discontinuity and disproportionation) or 1 (for allylic discontinuity). The study of effect of quantity of initiator on telomer compositions and yields was conducted in the following telogen concentration intervals - BP (benzoyl peroxide) $11 \cdot 10^{-3}-82 \cdot 10^{-3} \mathrm{~mol} /$ liter and AIBN (azo-bis-isobutyronitrile) $24 \cdot 10^{-3}$ $163 \cdot 10^{-3} \mathrm{~mol} /$ liter.

As we see from Fig. 10, with the increase of concentrations of BP and AIBN initiators up to some limit, the linear dependence between telomer yield and square root of initiator concentration takes place.

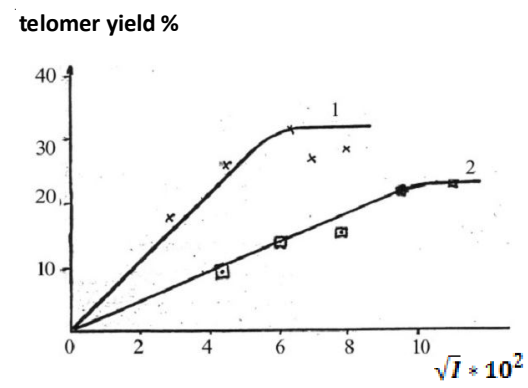

Fig. 10. Effect of initiator on telomer yields:

1 - Benzoyl peroxide, $t=120^{\circ} \mathrm{C}, t=2.5$ hours; $2-\mathrm{AIBN}, t=100{ }^{\circ} \mathrm{C}, t=1.5$ hours

It is found that the linear dependence takes place up to $27.5 \cdot 10^{-3} \mathrm{~mol} /$ liter for BP and up to $121.9 \cdot 10^{-3} \mathrm{~mol} / \mathrm{liter}$ for AIBN. Above these concentrations, linear dependence is no longer in place.

Based on Fig. 11, for BP with average concentration of $27.5 \cdot 10^{-3} \mathrm{~mol} /$ liter telomers are received with $\sim 49$ mol yield and for AIBN with similar concentration telomers are received with $\sim 18 \mathrm{~mol}$ yield per mole of initiator. Therefore, BP is 2.7 times as effective as AIBN. Thus, the length of kinetic chain for BP is $\sim 100$ and for AIBN it is $\sim 40$. Derived from experimental data, chain transmission constants are calculated at $100^{\circ} \mathrm{C}: c_{1}=94 \cdot 10^{-3} \pm 12.6 \cdot 10^{-3}$; $c_{2}=1.76 \pm 0.24 ; c_{3}=3.26 \pm 0.42$.

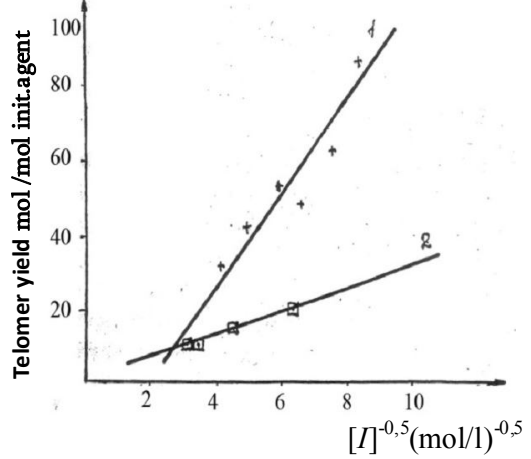

Fig. 11. Effectiveness of initiator:

1 - Benzoyl peroxide, $t=120^{\circ} \mathrm{C}, t=2.5$ hours; 2 - AIBN, $t=100{ }^{\circ} \mathrm{C}, t=1.5$ hours

Effect of Ethylene Molar Concentration on the Composition of Telomers

Fig. 12 describes the dependence of telomer composition change on molar composition of ethylene in the mixture at $100{ }^{\circ} \mathrm{C}$.

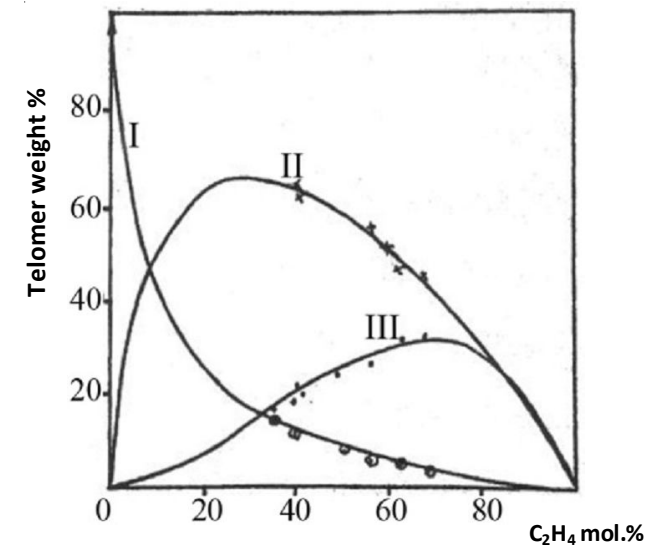

Fig. 12. The dependence of telomer composition change on molar composition of ethylene in the mixture at $100^{\circ} \mathrm{C}$ : $I$ - telomer $n=1 ; I I-$ telomer $n=2$; $I I I-$ telomer $n=3$

As we see from the diagram, when ethylene concentration goes to zero in the original mixture, telomer $n 1$ composition reaches $100 \%$. In case of significant increase of ethylene concentration in initial mixture, the quantity of lower order telomers approaches zero and upper order telomers $(n>3)$ will be the major products of telomerization reaction.

The curves $n=2$ and $n=3$ have maximums. Therefore, the adequate composition of ethylene in the mixture to receive $n=2$ (70 weight $\%)$ is $45 \mathrm{~mol} \%$ and to receive telomer $n=3$ (33 weight \%) is $80 \mathrm{~mol} \%$. 


\section{ТЕХНИКО-ТЕХНОЛОГИЧЕСКИЕ ИННОВАЦИИ}

According to the data from this study, it is recommended to conduct telomerization reaction of ethylene and trichloracetic acid ethyl ester under the following conditions:

$\begin{array}{lr}\text { Initiator BP } & (0.5 \mathrm{~mol} / 1 \text { telogen }) \\ \text { Telogen/Oliphin ratio } & 1: 0.8 \\ \text { Temperature } & 100^{\circ} \mathrm{C} \\ \text { Reaction time } & 1 \text { hour }\end{array}$

\section{REFERENCES}

1. Chkhubianishvili N., Kristesashvili L. Study of Ethylene Dilution in Trichloracetic Acid Ethyl Ester. The Works of Georgian Technical University, 2002, no. 6 (445), pp. 58-60. (in Georgian).

2. Karapetyants M.Kh. Chemical Thermodynamics. $4^{\text {th }}$ ed. Moscow, Khimiya Publ., 2013. 584 p. (in Russian).

3. Thermodynamics of Telomerization Reaction of Ethylene and Trichloracetic Acid Ethyl. Georgian Chemical Journal, 2009, vol. 9, no. 2, pp. 130-132. (in Georgian).

\section{ИССЛЕДОВАНИЕ РЕАКЦИИ ТЕЛОМЕРИЗАЦИИ ЭТИЛЕНА}

\section{Чхубианишвили Нодар}

Доктор технических наук, профессор, факультет химических технологий и металлургии, Грузинский технический университет rusikoch@yahoo.com ул. Костава, 77, 0175 г. Тбилиси, Грузия

\section{Кристесашвили Лали}

Доктор технических наук, профессор, факультет химических технологий и металлургии, Грузинский технический университет rusikoch@yahoo.com ул. Костава, 77, 0175 г. Тбилиси, Грузия

Аннотация. Интерес к радикальной теломеризации вызван тем, что она позволяет получить сравнительно низкомолекулярные длинноцепочные органические вещества с различными функциональными группами, которые трудно получить с помощью обычных методов и которые могут быть широко применены на практике. Реакция теломеризации этилена и трихлоруксусной кислоты этилового эфира представляет особый интерес. Реакция протекает следующим образом:

\section{$\mathrm{nCH} 2=\mathrm{CH} 2+\mathrm{CCl} 3 \mathrm{COOEt} \rightarrow \mathrm{Cl}(\mathrm{CH} 2 \mathrm{CH} 2) \mathrm{nCCl} 2 \mathrm{COOEt}$}

Теломеры, полученные из эфира этилена и трихлоруксусной кислоты, используются для получения психотропных препаратов, таких как гамолон, $\varepsilon$-капрон ( $\varepsilon$-капроновая кислота) и биологически активных веществ, например лизина и мехиона.

Ключевые слова: реакция, теломеризация, этилен, трихлоруксусная кислота, этиловый эфир, механизм, реакционная способность. 